\title{
How Farmers Cope with Risk and Stress in Rural Gambia ${ }^{1}$
}

\author{
Housainou Taal
}

\section{INTRODUCTION}

\section{Sources of Farm Risk}

Farm risk is defined as any event, be it environmental or socio-economic, that could make the household's income or crop output fall below a minimum disaster level (Roumasset 1976). These risks have dimensions which are both climatic, and derived from price fluctuations and access to markets and food.

The need to ident ify and analyse the various sources of farm risk and how households cope with them has become increasingly important as a result of the continuing food crises in sub-Saharan Africa (SSA). Declining food output in SSA (World Bank 1988) and the recent acute famine crises both imply that many poor rural producers have become more vulnerable to food insecurity. The range of risks and stresses they face, and the coping st rategies they employ, have to be investigated and understood in order to see how rural development programmes can best help them.

This article presents findings from 15 months' field research carried out in 1986/87 in two villages (Dobo and Kundam) located in MacCarthy lsland and Upper River Division of The Gambia, and from secondary data. It concerns the range of sources of risk faced by farmers, their regular seasonal exposure to risks and stresses, their strategies for coping, and how these have changed over time.

\section{Rainfall Variation}

Gambian agriculture is still predominantly rainfed, so any prospect of long-term aridity can pose a serious threat to the livelihood of the rural inhabitants and the economy as a whole. Since the Sahelian drought of 1973, rainfall variation has become increasingly important to farmers, both in decision making and policy. There is still a major debate about increased long-term aridity versus periodic droughts, which occur every four or five years. In the Food Strategy Report commissioned by ODA (1981) various

' The author would like to thank the Ford Foundation for providing funding for the fieldwork. He is grateful to Michael Lipton for general discussions about risk aversion and agricultural development and to Diana Hunt and Robert Chambers for their helpful comments on an earlier draft. interpretations of rainfall data were summarised, and caution was expressed regarding trends towards longterm aridity.

However, data from CILLS/Club du Sahel and the Department of Hydromet are more supportive of increased long-term aridity. In the ClLLS/Club du Sahel report on the Development of Irrigated Agriculture (1979) it was revealed that rainfall data from Banjul in The Gambia from 1886 to 1977 shows a decline of 15.5 per cent. The Department of Hydromet fitted a trend line to rainfall data for Banjul from 1886 to 1977 and this indicated a decline of 25 per cent for that period. Furthermore, the CILLS/Club du Sahel (1983) report on the Development of Rainfed Agriculture in The Gambia pointed out the occurrence of very poor rainfall in seven years out of 14 ( 1968 to 1982) rather than the risk of drought every four to five years which is often assumed, based on earlier rainfall patterns.

Thus mean rainfall appears to have fallen, but it is not clear whet her variations from the mean have remained constant or increased. For rural producers, such decline in rainfall and continued wide fluctuations from year to year pose a serious threat to food security by enhancing vulnerability. Early planting is now essential since the rainy seasons are shorter. Poorer farmers are adversely affected, since early planting involves greater risks of crop failure and early utilisation of scarce inputs for production. Consequently, farmers tend to allocate their resources so as to assure survival, especially in difficult years of low rainfall, crop failures and food shortage.

\section{Price Variation}

Price fluctuations are influenced by both climatic and human factors, and have been marked over recent years. The prices of groundnuts, cotton and, to a lesser degree, paddy rice, are controlled by the government, while maize, sorghum and millet prices are determined by local supply and demand conditions. In real terms groundnut producer prices have been declining steadily, except for $1985 / 86$, when they rose sharply as a result of the Economic Recovery Programme (see Fig. 1). Real producer prices of cotton, The Gambia's other export crop, followed similar trends until 1987/88, when groundnuts fell but cotton rose. Apart from paddy rice, few data exist about price trends of 


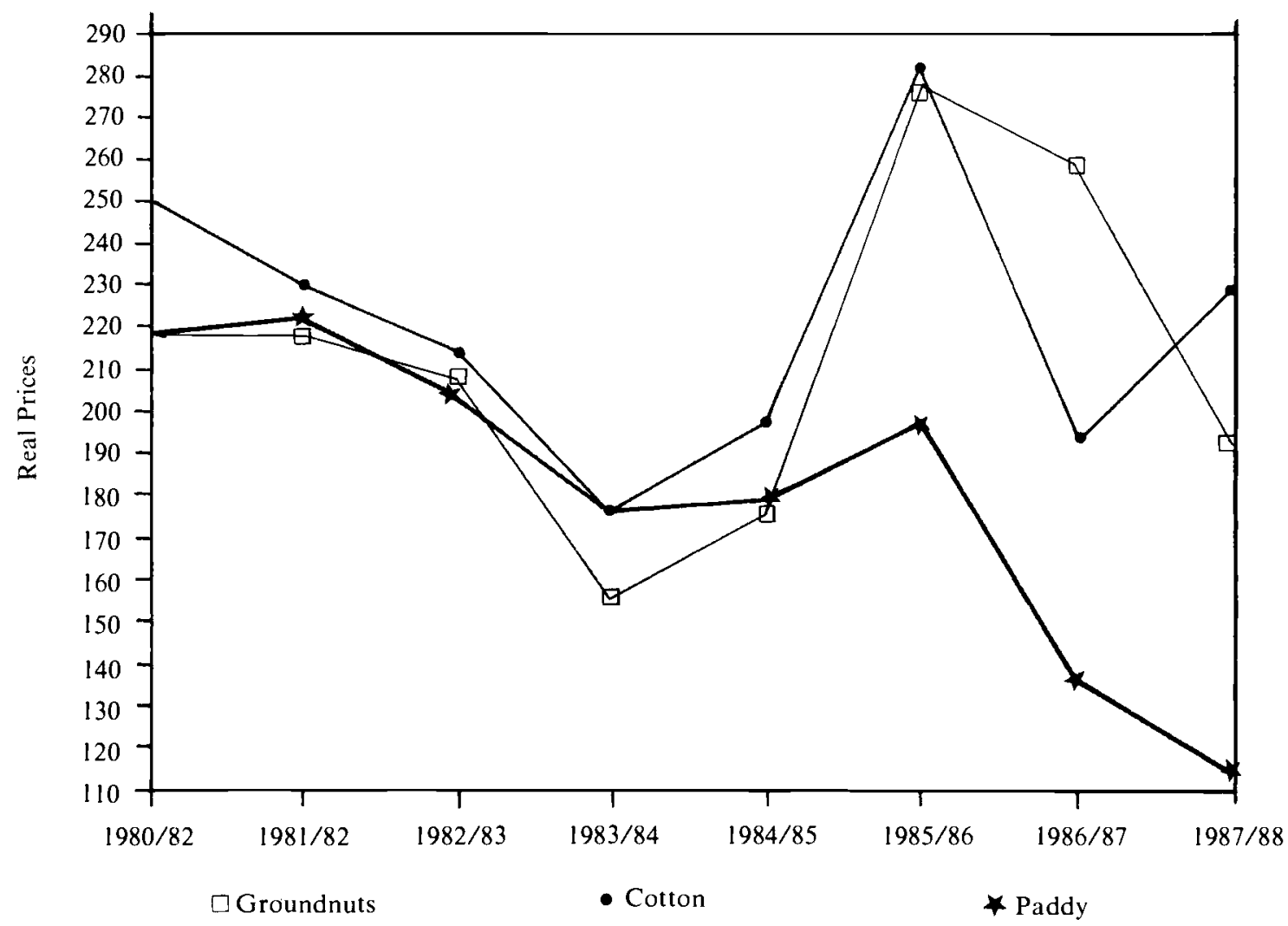

Note: Real Producer Prices are expressed in 1974 equivalents. 1 US \$ = D7.58 in January 1987. Source: Gambia Produce Marketing Board \& Central Statistics Dept.

food crops, especially maize and the coarse grains of millet and sorghum, but they appear to have declined in a manner similar to paddy rice, and are also very volatile in periods of drought and food shortage. Farmers' short-term economic vulnerability is reduced when prices rise, but they continue to be vulnerable to sharp, unpredictable fluctuations in which prices of different crops often move together.

\section{Access to Markets and Food}

There is a long history of the functioning of markets in major towns and villages of The Gambia well before colonisation and even during the difficult periods of war and destruction during the slave trade [Barrett 1988]. During the colonial period, groundnuts were introduced as a cash crop, and this brought a greater reliance on markets for the purchase of foodstuffs after farmers had sold their groundnuts.
In recent years the rural areas have seen the emergence of the 'lumo'. a weekly market where farmers and traders from nearby districts and from Senegal converge on a particular village or town to trade food crops such as rice, sorghum and millet, manufactured items, and livestock. The lumo is usually held in larger villages and towns, and its recent popularity symbolises the growing dependence of the rural poor on the market. Lumo traders can often be seen in small villages procuring grain or livestock, with the result that food deficit and poorer farmers will increasingly have to travel from their villages to the lumo to purchase food, possibly at higher prices.

While the lumo has made rural markets, especially in the livestock sector, more active, the functioning of both rural and urban markets remains vulnerable, especially in periods of drought when traded goods, and notably food, cannot meet demand, and are usually offered at exorbitant prices. 


\section{Regular Seasonal Stress}

Besides crises which occur irregularly, such as droughts, other natural disasters, and the effects of one or more years of poor harvest, farmers also face stresses which are seasonal and occurring every year.

The dominant feature of the Sahelo-Guinean climate of The Gambia is five months of intense wet season from early June to later October, and a dry season of seven months. In recent years the dry season has lengthened, and farmers have become more aware of the importance of early planting and careful resource management.

The end of the dry season and the beginning of the rainy season is a particularly difficult period in rural villages [see Chambers, Longhurst, and Pacey (eds.) 1981]. Work loads are very high, since both ploughing and planting take place at this time (June/July). Consequently, energy needs are very high for most of the rainy season. Longhurst cited previous research in The Gambia and Ghana showing that adults lose about five to seven per cent of their body weight during the wet season, when energy expenditure usually exceeds energy intake [Longhurst 1986:29]. Furthermore, this period of very high energy need is when several farmers run out of food and there are more illnesses. Many farmers, especially those who are low-income, assetless, and in food deficit, are particularly vulnerable at this time since they have to purchase food at speculative prices and/or obtain loans at high rates of interest to buy food. Food prices tend to reach their peak during the hungry period (i.e. between planting and harvest) and fall gradually after the harvests start, around September and October.

Farmers are well aware of the hungry period, since it greatly influences how they allocate their resources. By maximising their food output farmers hope to enhance their food security and increase their potential to survive. The persistent problem facing farmers is uncertainty about the extent to which they will be affected during the hungry period, which varies from year to year and depends largely on the previous harvest, the existence of food stocks, the functioning of rural markets and individual wealth.

The different risks - from climate, especially rainfall; from the economy, especially prices; and from lack of access to food through the market - combine to aggravate the vulnerability of farm households. As we have seen, they also intensify seasonally in their impacts. In The Gambia, as in other similar tropical agricultural systems, farmers' risk aversion is reflected in their strategies for minimising these risks and for coping with the stress and crisis to which they can lead.

\section{RESPONSES TO FARM RISK}

There are several ways in which farmers can reduce the risk of crop failure or cope with food insecurity. Such mechan isms vary from place to place and depend also on the level of the distress involved, but some general patterns of coping with such problems have been identified. Watts (1983), Cutler (1986), Rahmato (1987), and de Waal (1984) in their field studies of famine and coping strategies in sub-Saharan Africa have all emphasised the existence of a sequence of responses that households employ to deal with food insecurity and famines. These responses were summarised by Corbett (1988) into three broad stages: (i) insurance mechanisms, e.g. changes in cropping pattern and planting practices, reduced consumption, inter-household transfers, etc.; (ii) disposal of productive assets (divestment), e.g. sale of large livestock, agricultural tools, mortgaging of land or obtaining credit; and (iii) destitution, e.g. distress migration and starvation. Watts' study of the 1973/74 famine in Northern Nigeria is unique in extrapolating inter-household differences mentioned earlier by Hill (1972), and in mapping out differences in coping strategies between rich and poor households:

... while the poor resorted to the sale of livestock, pledged farms, incurred debts, sold their labour power, and borrowed grain at usurious rates, their wealthy counterparts bought stock at deflated prices in conditions of oversupply, sold or lent grain to needy families, purchased wage labour at depressed rates and purchased the scarcest resource of all on their own terms, namely land... In Kaita village the success of households to accommodate drought depended largely on access to land, capital accumulation during non-drought years, and the facilities for capital restoration after the period of asset depletion [Watts 1983:440-41].

Thus even within the same community strategies vary sharply between rich and poor households, and the rich can gain from crises. Since it is the poorer who are more vulnerable, it is with their strategies that we are most concerned. These can be illustrated by examining the range of coping mechanisms employed in the two study villages, especially by the poorer farm households.

\section{Choice of Cropping Pattern}

In the past decade or so, the falling price of groundnuts in real terms (see Fig. 1) together with increased climatic uncertainty and poor rainfall have prompted farmers to diversify their production in two ways. Firstly, there is the cash/food crop decision, through which farmers have given more attention to food crops (e.g. coarse grains) because of poor prices in real terms and the risk associated with cultivation of 
Reason

Village

Kundam Dobo

Total

More efficient use of labour

More output and food per unit area

More certain of yield

Tradition

$\begin{array}{rrr} & 6 & 2 \\ 68 & 81 & 73 \\ 29 & 13 & 23 \\ 4 & & 2\end{array}$

cash crops such as cotton, and, to a lesser extent, groundnuts. For example, the production of early millet in The Gambia increased from 7,000 tons in $1974 / 75$ to 43,000 tons in $1985 / 86$. It is also not surprising that the area under early millet production increased from 6,000 hectares to about 38,000 hectares, while the groundnut area fell between 1974/75 and 1985/86 from about 105,000 hectares to 66,000 hectares [PPMU 1986].

Secondly, there is also the strategy of growing crop mixtures to offset the risk of crop failures and enhance food security. Table 1, for example, shows that nearly three quarters ( 73 per cent) of the sample of 45 household heads interviewed in Dobo and Kundam said that they practised mixed cropping in order to have more output and higher food returns per unit area. Stable yields was the second most popular response: farmers who opted for this said that they practised mixed cropping so that if one crop failed then the other would succeed. Very few farmers cited tradition or more efficient use of labour as reasons for practising mixed cropping.

The other development which has intensified in recent years is the shift from swamp rice cultivation by women farmers to the production of groundnuts, especially in the Upper River Division where swamp rice yields are poor and uncertain, and there is a need to utilise labour resources more efficiently. The women divide their time between swamp rice and groundnut cultivation to spread risks, reduce vulnerability, and increase their incomes, adapting to the more rapid fall in recent years of the real price of paddy rice compared with groundnuts.

\section{Crop Storage}

Storage of food crops is a popular means of ensuring food security, especially at the village level. The harvests of early millet and maize take place around September, and consumption of such crops begins at harvest time and may carry the household through for a couple of weeks to months. From late September/
October onwards harvest of late millet, groundnuts, cotton and swamp rice takes place, and such harvests provide better prospects for crop storage because early crops are almost always consumed just after harvest, since food stocks are extremely low at this time of year.

Food crops are stored in several locations in the compound; they are sometimes tied in bundles and kept in mud-brick stores, houses, or in thatched grain silos with raised platforms. The poorer households tend to exhaust their food stocks much earlier, and have to purchase milled rice, take loans or request gifts from friends or relatives to tide them over until the next harvest. The most vulnerable period is late August, before the arrival of the early harvests in late September and October. Almost all the poorer households in our sample had empty stores or very low stocks, so grain was either purchased or obtained from another source.

\section{Reduced Consumption}

Reduced consumption as a resource management strategy becomes more pronounced in the wet season when food stocks are low and the harvest is yet to come. In Dobo and Kundam the groundnut stew 'durang', which is cooked with dried fish and vegetables such as tomatoes and onions is an essential feature of the diet. During the wet season, or whenever food becomes scarce, durang is replaced with the less nutritious 'katcha', another kind of stew made almost entirely from saurel leaves grown in gardens or backyards. Both men and women actively try to solve such food crises, the men searching for alternatives such as credit or off-farm work to provide rice or cereal, and the women working hard to collect edible leaves or fruits to ensure that the cereal is served with something nutritious. In more serious cases of food shortage, meals are missed or the amount of food cooked is reduced. Such strategies are more likely to be adopted when food stocks are very low and the farmers have to use credit or other means to provide for their families. 


\section{Off-Farm Work}

In times of food security, it is not uncommon for a male member of the household to go to the town or city to look for work, returning home later. This strategy, however, is more feasible for wealthier or larger households which are less affected by the absence of a productive member of the household.

Within the villages, the occupation castes such as male blacksmiths and leatherworkers and women weavers and potters do earn significant off-farm income, and in some cases their work carries on even during the wet season. Market gardening is also very popular among women, although this cannot be considered as offfarm income. Market gardening helps to improve the diet of the household as well as providing some income through the sale of vegetables in village markets or towns. Petty trading in essential commodities such as rice, sugar, kerosene, candles and matches also takes place throughout the year, but is dominated by the wealthier farmers or those able to obtain credit for the initial capital investment.

\section{Asset Disposal}

In times of distress and food shortages, asset disposal is a widely practised strategy. In The Gambia extreme forms of drought and famine have not been experienced in recent decades, although 1974 was a very bad year. The famine in Ethiopia in 1974, 1984 and 1988, and in the Sudan and Sahel in 1985 provide evidence of strategies in conditions of extreme human misery and suffering. There is a common but not universal sequence of asset disposal, with poultry. sheep and goats sold first, followed, as the situation becomes worse, by much more valued assets such as cattle, jewellery or farm equipment. As food shortages develop and become more acute, richer farmers and livestock traders initially benefit through the purchase of livest ock from poorer farmers. As drought worsens, however, almost everyone is adversely affected as a stage of destitution is reached involving large-scale migration as humans and livestock begin to die of hunger, and only outside help from governments or international relief agencies can rescue those affected.

\section{Community and Kinship Ties}

Community and kinship ties often play a crucial role in minimising vulnerability, especially at the onset of crop failures, depletion of food stocks, and very high food prices. In Dobo and Kundam, these operate at the level of wards (kabilolu - singular kabilo) and of age grade work groups (kafolu - singular kafo). A kabilo usually relies on kinship ties through the extended family, although strangers may also become members. Kabilo members are expected to help each other in times of difficulty. They form a kafo to help each other in farm work with a discount to members, as well as to offer hired labour to non-kafo members.

Community and kafolu organisation are also the basis for minimising crop losses and for diversification. At the community level, minimising crop damage by birds before and during harvests of early millet requires the cooperation of a large section of the communitv. At the kafolu level, the Department of Community Development and Catholic Relief Services have been supporting diversification by trying to introduce beniseed cultivation in villages, mainly through women's kafolu.

The giving and receiving of gifts is also a useful mechanism of income redistribution in village communities. Under Islamic law a certain percentage of a person's wealth (zakat) must be given as alms to the poor. In both villages the zakat amounted to between eight and 10 per cent of all food crops harvested. The amount of zakat given out by richer farmers can be very significant. There are also transfers of zakat from one low income farmer to another, since no-one is exempt from this obligation. Reciprocal relationships through gifts are not restricted to one village: sometimes farmers travel to other villages of distant kin to reinforce kinship ties and receive or give help as necessary.

\section{Evolution of Household Strategies}

Rural households should be conceptualised as rapidly changing units which must adapt to change. The literature [see Corbett 1988] on household coping strategies, for example, identifies sequences of responses made by households, but such responses would be better understood if the socio-economic nature of the household and its historical evolution is taken into account. For instance, strategies to deal with food insecurity and famines today may be quite different from those used several years ago.

In rural Gambia, examples from Dobo and Kundam can illustrate how household strategies have been affected by changes in socio-economic relations between households. The two villages are divided into three kabilolu (wards) which are further divided into compounds and then into smaller consumption units called 'sinkirolu'. (Sinkirolu is the plural of sinkiro in Mandika which represents a consumption unit or pot. The syllable lu is added to the end of many singular nouns in Mandika to make them plural.) On average there are slightly less than two sinkirolu in a compound.

It is becoming increasingly common for each sinkiro to make separate decisions concerning production and consumption, although one of the sinkirolu is usually dominant. (The term sinkiro is used alternatively with the term household since they both refer to a consumption unit.) In the past there used to be one 
main sinkiro for every compound and the compound head usually made most important resource allocation decisions. However, this pattern is changing rapidly due to the increased commercialisation of the rural economy. In one extreme example in Kundam a compound had up to eight sinkirolu in the dry season of 1986, but the compound head explained that in times of food shortages during the rainy season the sinkirolu contract to two, in order to combine resources and combat hunger more efficiently.

Each sinkiro is supported by a 'dabada' (a collective work force). There is a strong correspondence between the dabada and the sinkiro in well over 90 per cent of our sample of 45 households. A field cultivated by a dabada is called a 'maruo' (collective field) while an individually cultivated field is called a 'kamanyang'. The main objective in cultivating the maruo is to provide the sinkiro with sufficient food, a function which goes back many years when production was primarily for subsistence, and commercialisation of agriculture was minimal. The matuo has retained its traditional role of food provision, but it also helps the household to secure as much cash as possible to meet its growing needs. Thus nowadays maruolu comprise mainly food crops but include cash crops as well. Sorghum, millet, maize, swamp, irrigated and upland rice, as well as groundnuts, are typical maruo crops. The threat of food shortages and hunger in recent years has pressured farmers into giving more attention to their maruolu than they would have done in years of food surplus.

It appears also that household size and status does influence the ability of the sinkiro to meet its food needs, since large households tend to have a larger number of producers, a higher producer/consumer ratio, and higher income in general. A large workforce enables diversification of crop cultivation into drought resistant and risky crops, as well as crops with low and high labour requirements.

Another major aspect of household strategy is the division of labour along gender lines, and the active roles played by women, especially in food production and processing. Gender division along crop lines has become les distinct as men venture into irrigated rice and women into groundnut culitivation, especially in Upper River Division. However, women still bear a disproportionate share of the burden in raising young children and food processing. Market gardening among women has alos become more important in recent years as several dried swamp rice fields have been converted to market gardens to provide better nutrition and income for the household.

\section{CONCLUSION}

Farming in the study villages has become riskier over recent decades. Vulnerability has increased, especially that of the assetless and the poorest. In response, coping strategies have diversified. Rural households are not static objects that respond arbitrarily to food insecurity or drought; rather, they carefully utilise strategies which help them evolve and adapt to their rapidly changing environments. Their responses to food insecurity and drought include choice of cropping pattern, crop storage, reduced consumption, off-farm work, asset disposal, and making claims on community and kinship ties. The responses vary and may follow sequences, with a poor household likelier to sell its large productive assets (e.g. draught animals or farm equipment) sooner to purchase food in time of food crisis than a richer household, which has more options. As vulnerability increases coping strategies will be further diversified, but some will weaken. Collective cultivation to provide food security, for instance, can be expected to decline as commercialisation continues and farmers find it more profitable to grow cash crops on their own. Policy makers must recognise these trends of increasing vulnerability in the rural sector and devise interventions to help farmers cope with their situations. This raises issues of agricultural prices to increase farm incomes and so decrease vulnerability, and of credit, food aid, nutrition, and rural technology programmes geared to the needy and to those households which have the greatest potential for improvement. With all such interventions, the question deserves to be asked whether they can be so designed and implemented that they will indeed offset recent adverse trends, and decrease the risks, stresses and vulnerability of poor farm households.

\section{References}

Barrett, H. R., 1988, The Marketing of Foodstuffs in The Gambia 1400-1980: A Geographical Analysis, Gower, Aldershot

Chambers, R., Longhurst, R., and Pacey, A. (eds.), 1981, Seasonal Dimensions to Rural Poverty, Frances Pinter, London

CILSS (Permanent Interstate Committee for the Control of Drought in the Sahel/Club du Sahel), 1979, Development of Irrigated Agriculture in The Gambia: General Overview and Prospects, Proposals for a Second Programme 1980-85, CILSS/Club du Sahel, SAHEL D (79) 48, Paris

CILSS/Club du Sahel, 1983, The Development of Rain-fed Agriculture in The Gambia, CILSS/Club du Sahel, Paris

Corbett, J., 1988, 'Famine and household coping strategies', World Development, vol 16, no 9, pp 1099-1112

Cutler, P., 1986, 'The response to drought of Beja famine refugees in Sudan', Disasters, vol 10, no 3 
de Waal, A. and El Amin, M., 1984, 'Survival in Northern Darfur 1985-86, Report to Save the Children Fund, Nyala, Sudan

Hill P. 1972. Rural Honsa: A I'illage and a Seming. Cambridge University Press

Longhurst, R., 1986, 'Household food strategies in response to seasonality and famine, $I D S$ Bullom, vol 17, no 3

ODA, 1981. The Gambia Food Sralegy Reporl, ODA. London

Planning, Programming and Monitoring Unit (PPMU) for the Agricultural Sector, 1986, Crop Producrion Pallorn for the poriod 1974/75-1985/86 and Arable Land, Minist ry of Agriculture, Banjul
Rahmato, D., 1987, 'Famine and Survival Strategies: a Case Study from North East Ethiopia, Food and Faminc Monograpl' Series no 1, Institute of Development Research, Addis Ababa University, Ethiopia

Roumasset. J. A., 1976, Rice and Risk: Decision Making among Low Inconc' Farmers, North-Holland, New York

Watts, M., 1983, Silen Violence: Food, Famine and Peasanmy in Norhern Nigoria, University of California Press, Berkeley

World Bank, 1988, Woild Developmen Repor 1988, Oxford University Press, New York 